ISA

Arboriculture \& Urban Forestry 2014. 40(4): 230-236

\title{
Pruning of Buttress Roots and Stability Changes of Red Maple (Acer rubrum)
}

\author{
E. Thomas Smiley, Liza Holmes, and Bruce R. Fraedrich
}

\begin{abstract}
The purpose of this study was to evaluate the effects of buttress root pruning on tree stability and to compare different methods of correlating various root parameters to force levels. Ten plantation-grown Acer rubrum (red maple) trees were pulled to an angle of one degree from vertical with measured force, then roots were individually severed near the trunk and the pull tests were repeated until roots had been pruned from $50 \%$ of the circumference. Test trees had 6 to 10 buttress roots. There was a nearly direct linear relation between the number of roots removed and the force applied. When comparing four assessment methods to determine pull force change associated with root pruning, the method that had the greatest amount of variability explained by the regression was the comparison of the cross-sectional area of roots cut to the force. However, relating the percentage of buttress roots cut to the force provided only slightly less accurate information, and was more easily collected prior to tree removal.

Key Words. Acer rubrum; Buttress Roots; Likelihood of Failure; Pull Test; Red Maple; Root Cutting; Root Pruning; Root Stability; Tree Stability; Trenching.
\end{abstract}

The International Tree Failure Database reports that $35 \%$ of recorded tree failures were root related (ITFD 2013). Root failure patterns vary with tree species, size, age, and soil conditions (Mattheck et al. 1997; Stokes 1999; Mickovski and Ennos 2003; Dupuy et al. 2005b). Anchorage strength was found to be proportional to trunk diameter in several studies (Stokes 1999; Mickovski and Ennos 2003). When roots are decayed, cut, or damaged, tree stability and health may be reduced (Matheny and Clark 1994; Hamilton 1998; Smiley et al. 2011). The threshold point at which root loss increases the risk of tree failure has not been well studied (Mattheck and Breloer 1994; Fraedrich and Smiley 2002). Therefore, additional information is needed to determine the degree of root loss that a tree can tolerate without causing a significant change in stability. This information is important to arborists who assess tree risk; engineers who specify root pruning, such as the pruning associated with sidewalk replacement; homeowners who prune roots to reduce foundation damage; and others involved with root cutting or pruning.

Forest research on tree stability has focused on pulling trunks or tall stumps to the point of failure
(Coutts 1983; Crook and Ennos 1996; Mickovski and Ennos 2002; Mickovski and Ennos 2003; Ghani et al. 2009). An alternative method is the static pull test (Brudi and van Wassenaer 2002; Smiley 2008). Tension is applied to a tree using a cable, dynamometer, and winch, and the angle of trunk lean is measured. This method requires less force and does not destroy the tree, which allows researchers to test the same tree multiple times. Force to pull small Quercus phellos (willow oak) to a trunk angle of one degree correlated well with the force required to pull the trees to failure (Smiley 2008). This was consistent with Brudi and van Wassenaer (2002). The strength of this relationship allowed extrapolation of the one-degree pulltesting data to failure with some degree of reliability.

Tree root systems can be categorized based on the overall shape or woody root distribution (Busgen et al. 1929; Köstler et al. 1968). The three primary categories described were 1) tap root systems, 2) horizontal or plate root systems, and 3) heart root systems. It has been demonstrated that tap and sinker roots provide a major portion of the anchorage strength on some species, espe- 
cially pines (Smiley et.al. 2000; Mickovski and Ennos 2002; Dupuy et al. 2005a). Larger diameter, mature dicot trees often do not have oblique roots or tap roots due to species genetics, root decay, or soil depth limitation; thus, larger trees may be more susceptible to damage from lateral root cutting than the smaller trees (personal observation). Trees with tap or horizontal root system types may be affected differently by root cutting.

Buttress roots are roots near the base of the tree that support the tree and equalize mechanical stress (Lilly 2011). When these roots are significantly decayed or pruned, tree stability is reduced (Smiley 2008).

The purpose of this study was to evaluate the effects of buttress root pruning on tree stability and to compare different methods of assessing root loss. This type of individual root cutting was intended to simulate root loss from pruning or decay.

\section{MATERIALS AND METHODS}

Ten plantation-grown, 39-year-old Acer rubrum (red maple) trees with a mean diameter measured at $1.37 \mathrm{~m}(\mathrm{DBH})$ of $30 \mathrm{~cm}($ S.E. $=0.2)$ were selected for testing between August 23 and 26, 2010, at the Davey Research Farm in Shalersville, Ohio, U.S. (N41.235, W81.168, elevation $378 \mathrm{~m}$ ). Trees were spaced at $3 \mathrm{~m}$ within rows and $4.5 \mathrm{~m}$ between rows. The soil type at the site was a Ravenna silt loam with a $2 \%-6 \%$ slope. This soil type is somewhat poorly drained and has a water table at 15 to $45 \mathrm{~cm}$ (Soil Survey of Portage County, Ohio 1978)

Prior to conducting tests, the base of each tree was partially excavated using a supersonic air tool (Air-Spade $^{\mathrm{m}}$, GuardAir Corporation, Chicopee, Massachusetts, U.S. or Air Knife ${ }^{\mathrm{m}}$, Allison Park, Pennsylvania, U.S.) to expose the buttress roots.

Tree stability testing was conducted using the methodology described in Smiley (2008). Two roofing nails $(5 \mathrm{~cm})$ were driven into the trunk xylem 15 and $75 \mathrm{~cm}$ above grade. The nail at $75 \mathrm{~cm}$ was installed directly above the nail driven at $15 \mathrm{~cm}$. A digital level (Smart Level, MD Building Products, Oklahoma City, Oklahoma, U.S.) was strapped to the trunk of the tree to ensure contact with the two nails. The level was adjusted at the beginning of the pull test to read 90 degrees (+0.05 degree).

A dynamometer (Dillon ED-200+, Fairmont, Minnesota, U.S.) was attached to the trunk of the subject tree, using a webbing sling. A wire rope (11.5 $\mathrm{mm}$ in diameter) or cable was attached to the trunk at a height of $3 \mathrm{~m}$ and was run directly to a hand operated mechanical winch that was anchored to the base of another tree. The $3 \mathrm{~m}$ attachment height was chosen so as to provide significant bending moment at the base of the trunk while minimizing trunk bending. Trees were pulled so that the trunk achieved an angle of one degree from vertical. Force was released after each pull; this was repeated three times. The peak dynamometer reading was recorded for each pull. The average of the three peak readings was recorded and used for analysis. Angle of the pull line was measured for each tree. This procedure was defined as a "pull test."

After an initial pre-root pruning pull test, trees were subjected to "individual root cuts." These pruning cuts were made by vertically cutting the root in two planes close to the trunk using a chain saw or gas-powered masonry circular saw (Figure 1). A section of the root approximately $2 \mathrm{~cm}$ wide was removed to ensure that there was no connection between the trunk and root and to allow subsequent root size measurements. The cross section was preserved and later measured on the side closest to the trunk for height, width, and surface area.

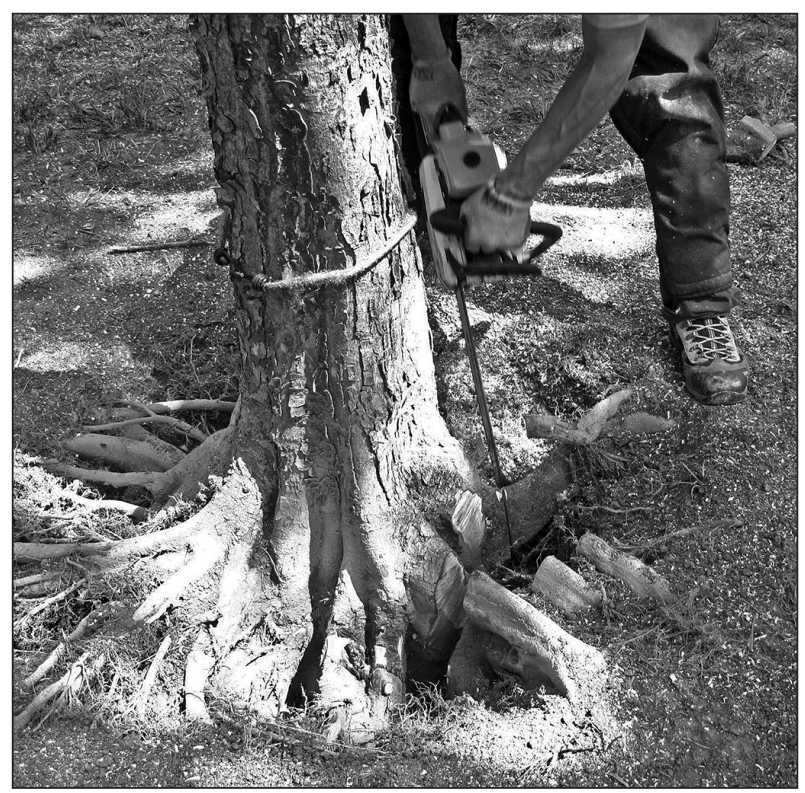

Figure 1. Root pruning procedure showing two severed buttress roots with sections removed and the third root in the process of being pruned. 
The first root cut was on the side of the tree opposite the pull line. After cutting the root, the tree was pulled again to one degree. This procedure was repeated, cutting roots on alternating sides of the first root cut until roots were pruned from approximately 50 percent of the root flare circumference, going 90 degrees around the stem from the direction of pull rope attachment, in two directions. Two root pruned trees were pulled to failure for the purpose of root examination.

Root loss can be evaluated using various measurements or methodologies to estimate the impact on tree stability. Four methodologies of measuring root loss were compared to the force required to pull the tree to an angle of one degree, to determine the correlation between the two parameters. Applicability for field use and degree of correlation were considered.

Method 1. The percentage of roots pruned was determined in the field by counting all significant buttress roots and then dividing the number of roots cut by the total number of buttress roots. The formula used was:

$$
\mathrm{R}_{\%}=\mathrm{R}_{\text {cut }} / \mathrm{R}_{\text {total }}
$$

where $R_{\%}$ is the percentage of buttress roots cuts, $\mathrm{R}_{\text {cut }}$ is the cumulative number of roots cut, and $\mathrm{R}_{\text {total }}$ is the total number of buttress roots on the tree.

Method 2. Maximum buttress root width was measured at the plane of severance using a caliper.

Method 3. An estimate of the cross-sectional area (CSA) of each pruned root was made by measuring the height and width of the root at the plane where it was severed. Root CSA was calculated using the formula for the area of an ellipse:

$$
\mathrm{R}_{\text {area est }}=(0.5 \times \mathrm{H}) \times(0.5 \times \mathrm{W}) \times \pi
$$

where $\mathrm{H}$ is the vertical distance from the top of the root to bottom the root and $\mathrm{W}$ is the root width, both measured in the plane of the pruning cut. Root height and width can be measured with a caliper after removing the soil from around the buttress root.

Method 4. A measurement of the actual CSA was made after root removal. The cross section of the root closest to the trunk was removed in the field, traced onto transparent plastic sheet, scanned, and the area within the traced line determined.
When assessing root CSA or width, the cumulative area or width was used in the comparison with the pull forces.

The measured CSA was compared to the estimated root CSA and to root width using a correlation procedure. Pull-force measurements were normalized to remove the influence of trunk diameter by dividing the peak force to move the trunk one degree after root cutting by the peak force prior to cutting any roots and multiplying by 100 . Root CSA and width values were also normalized for trunk diameter, by dividing the sum of root CSA or root widths by the trunk CSA at $1.37 \mathrm{~m}$.

Soil moisture was determined from five soil samples collected to a depth of $15 \mathrm{~cm}$ randomly throughout the plot. Samples were weighed after collection and again after drying for two days at $98^{\circ} \mathrm{C}$. Soil moisture was calculated by subtracting the dry weight from the wet weight and dividing by the dry weight.

Horizontal pull force $(\mathrm{kN})$ was calculated by multiplying the measured force by the cosine of the pull-line angle. Bending moment $(\mathrm{kN} \times \mathrm{m})$ at the base of the tree was calculated by multiplying the horizontal pull force by the height of the pull-line attachment above grade. Stress $\left(\mathrm{kN} / \mathrm{cm}^{2}\right)$ was calculated by dividing the horizontal pull force by the CSA of the trunk as measured at $1.37 \mathrm{~m}$.

Correlation coefficients and regression analyses were conducted on the data using SPSS (SPSS Inc., Chicago, Illinois, U.S.).

\section{RESULTS}

Forty-nine pull tests were conducted on the ten trees and 39 roots were pruned. Trees had 6 to 10 buttress roots each; the mean number of roots per tree was eight. Each root represented 10\%-16\% of the total number of buttress roots. Mean root width was $10.4 \mathrm{~cm}($ S.E. $=0.62)$, and mean root height was $20.3 \mathrm{~cm}($ S.E. $=1.1)$. The mean estimated root cross-sectional area was $178 \mathrm{~cm}^{2}$ (S.E. $=16.3$ ) per root and the mean measured area was $146 \mathrm{~cm}^{2}($ S.E. $=12.9)$ per root. Soil moisture level at the time of testing was $38 \%(\mathrm{w} / \mathrm{w})$.

Mean horizontal force required to move the trunk one degree from vertical was 12.6 $\mathrm{kN}$. Mean bending moment prior to root cuts was $37.8 \mathrm{kN} / \mathrm{m}$, and mean stress level based 


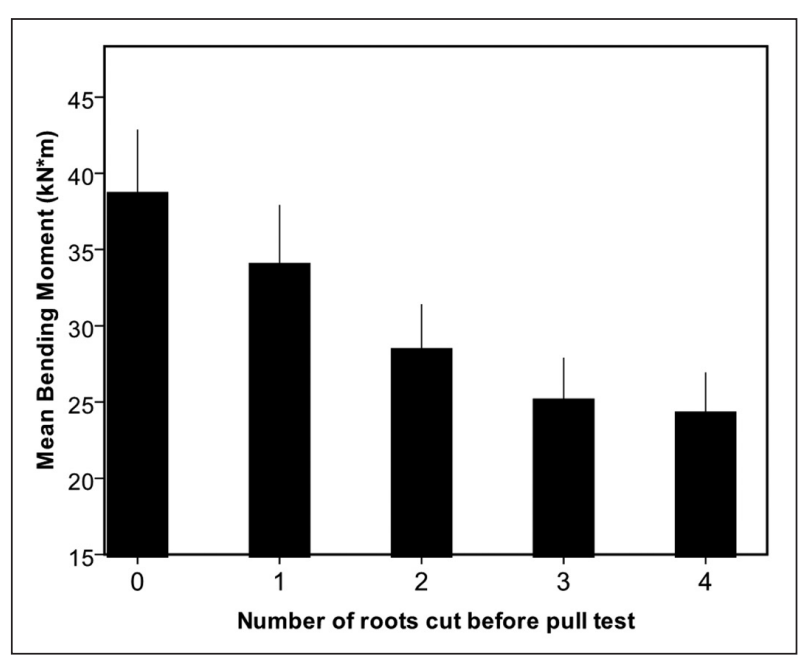

Figure 2. Bending moment to achieve one degree of trunk movement. Small bars indicate one unit of Standard Error.

on $\mathrm{DBH}$ was $0.17 \mathrm{kN} / \mathrm{cm}^{2}$. With each root cut, the force required was reduced (Figure 2).

The correlation between the estimated root CSA (Method 3, Equation 2) and the measured CSA was highly significant $(0.01)$ with a correlation coefficient of $95 \%$. The correlation between measured root CSA (Method 4) and root width (Method 2) was also highly significant with an $82 \%$ correlation coefficient.

The regressions used to compare root cut assessment methods with the normalized pull force produced a range of $r^{2}$ values. The percentage of roots cut (Method 1), root widths (Method 2), and the estimated CSA (Method 3) methods had $\mathrm{r}^{2}=0.74$, 0.54 , and 0.51 , respectively (Figure 3; Figure 4; Figure 5). The method with the greatest $r^{2}$ value was with cumulative root CSA (Method 4), which was highly significant with an $r^{2}=0.82$ (Figure 2).

Using the results from Method 1 (Figure 2), it can be seen that the first root cut resulted in a mean force reduction of $13 \%$. When $50 \%$ of the roots were cut, the average force reduction was $47 \%$ (Figure 4).

Both of the root cut trees that were pulled to failure had unsevered oblique roots growing in the area below the trunk (Figure 6). This indicates the presence of a "heart root" system.

\section{DISCUSSION}

The effects of cutting individual roots on tree stability were highly variable on these mature red maples. With most of these trees, cutting one root $(10 \%-16 \%$ of all buttress roots) had little impact on tree stability, reducing the pull force by an average of $13 \%$.

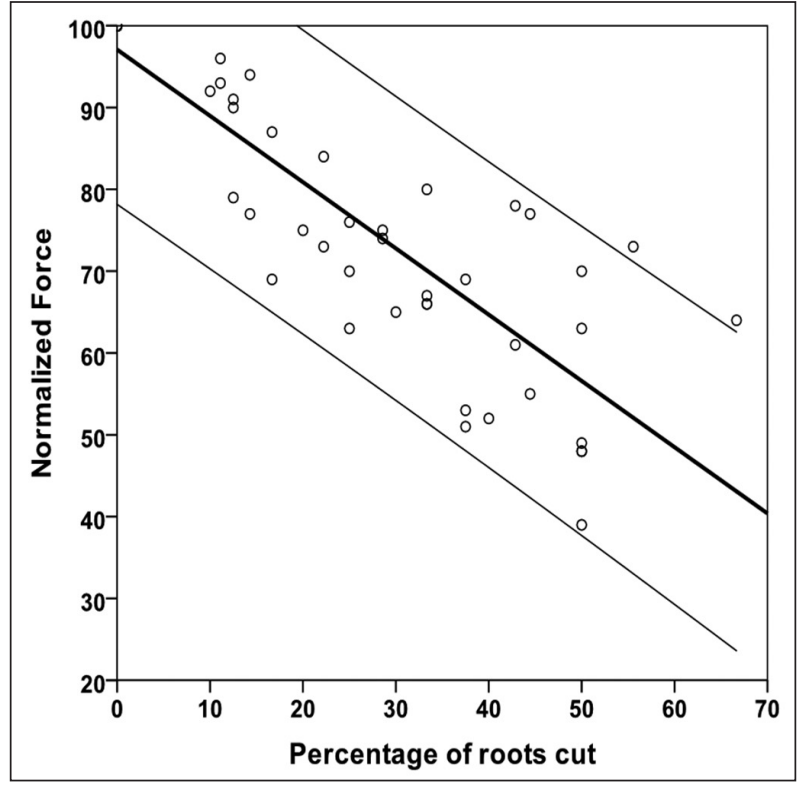

Figure 3. Regression line and $95 \%$ confidence interval for the comparison of the percentage of buttress roots cut $\left(R_{\text {cut }} / R_{\text {Total }} \times 100\right)$ and the normalized force (peak force to move the trunk one degree after root cutting divided by the peak force prior to cutting roots multiplied by 100) to move the trunk one degree. This assessment procedure was defined at Method 1. $F_{\text {Std }}=97-0.8\left(R_{\text {cut }} / R_{\text {Total }} \times 100\right), r^{2}=0.74$.

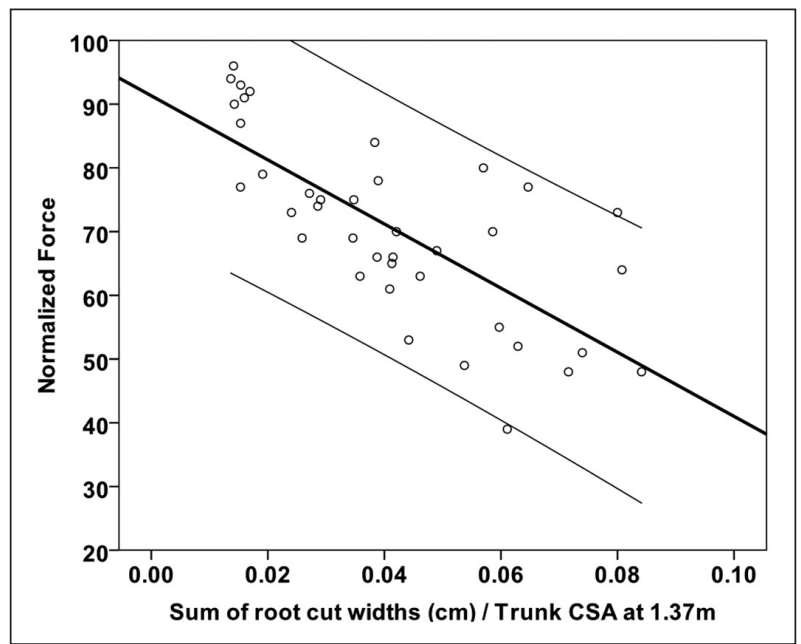

Figure 4. Regression line and $95 \%$ confidence interval for the comparison of the normalized cumulative sum of the widths of buttress roots cut divided by cross-sectional area of the trunk as measured at $1.37 \mathrm{~m}\left(\sum \mathrm{R}_{\text {cut width }} / \mathrm{CSA}_{\text {trunk }}\right)$ and the normalized force (peak force to move the trunk one degree after root cutting divided by the peak force prior to cutting roots multiplied by 100 ) to move the trunk one degree. This assessment procedure was defined at Method 2. $\mathrm{F}_{\mathrm{Std}}=91.3$ $-503 \times \sum R_{\text {cut width }}, r^{2}=0.54$.

However, on one tree, the force was reduced by $31 \%$ after severance of one root (Figure 3). As more roots were cut, the force levels decreased. When one-third 


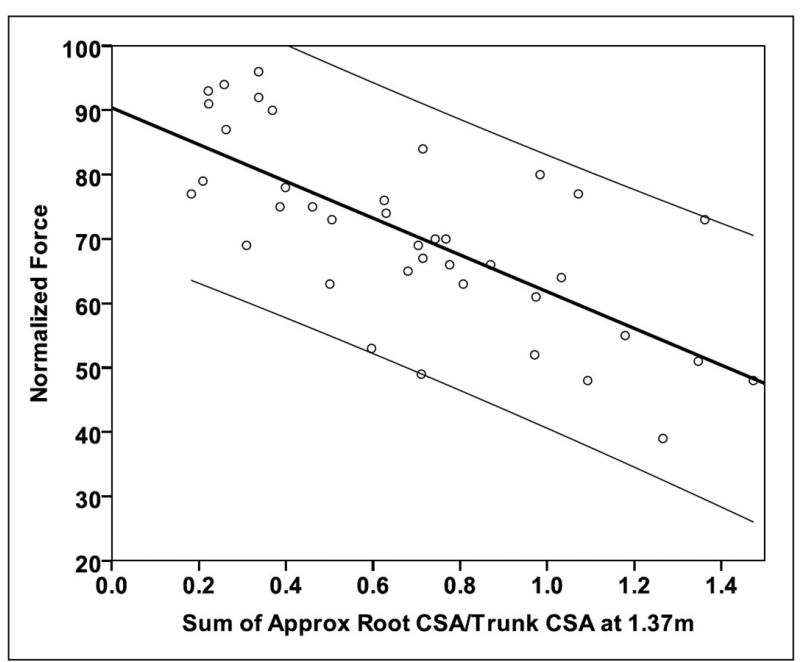

Figure 5. Regression line and $95 \%$ confidence interval for the comparison of the cumulative sum of the estimated cross sectional area of all roots that were severed divided by cross-sectional area of the trunk as measured at 1.37 $\mathrm{m}\left(\sum \mathbf{R}_{\text {cut area approx }} / C S A_{\text {trunk }} \times 100\right)$ compared to the normalized force $\left(F_{\text {Std }}=\right.$ peak force to move the trunk one degree after root cutting divided by the peak force prior to cutting roots multiplied by 100$)$ to move the trunk one degree. This assessment procedure was defined at Method 3. $F_{\mathrm{Std}}=90.4-$ $28.6\left(\sum R_{\text {cut area }} / \mathrm{CSA}_{\text {trunk }} \times 100\right), \mathrm{r}^{2}=0.51$.

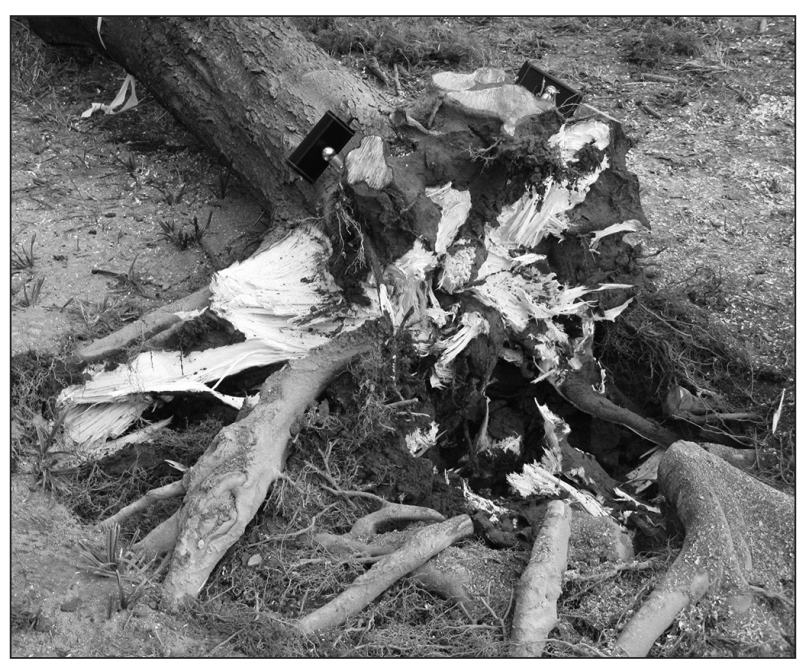

Figure 6. Red maple pulled to failure showing both cut buttress roots and broken oblique roots.

of the roots were severed, the force was reduced by about $35 \%$. When half of the roots were cut, force was reduced on average by $47 \%$. The mean number of roots severed therefore had a nearly direct linear relation to the force. These relationships are somewhat different from root-severed willow oak trees, where force levels were reduced to a lesser degree with each root cut (Smiley 2008). In that research, there was only a $20 \%$ reduction in force with $30 \%$ of the roots cut and a $33 \%$ reduction with $50 \%$ of the roots severed. This indicates that the smaller willow oaks may have a larger percentage, or more efficient, oblique roots than the red maples, thus the stability is not as affected by buttress root pruning. Working in conjunction with the buttress roots, oblique and deep roots play an important role in tree stability on small trees (Stokes and Mattheck 1996).

When comparing four methods of assessing the degree of root loss associated with the change in pull forces, the method with the greatest amount of variability explained by the regression was the comparison of the measured CSA of roots cut to the force (Method 4, Figure 7). However, that method is very difficult or impossible to apply when the roots are intact.

When evaluating root loss, relating the percentage of buttress roots lost to the total number of buttress roots (Method 1, Figure 2 and Figure 3) provided slightly less accurate information than Method 4 but was the easiest of the four methods to use in the field. Method 2 and Method 3 were considerably more difficult to apply and had lower $\mathrm{r}^{2}$ values than Method 1 .

Linear root cutting has been studied more than individual root pruning. A critical distance for linear root cut trees is a radius within three times the trunk diameter $(\mathrm{DBH})$, where a significant change in force occurred with willow oak and Eugenia grandis (Smiley 2008; Ghani et al. 2009). Cutting any roots at the trunk may increase the risk of premature tree failure. Roots on the uphill side of a tree or those on the side opposite of a trunk lean or a large individual root may be more important for tree stability than their individual percentage of the root system reflect (Smiley et al. 2002; Smiley et al. 2011).

Response growth (as seen as new root development) associated with root severance may reduce the likelihood of failure over time, while decay that may move into severed root surfaces may increase the likelihood of tree failure.

Most tree failures occur due to the dynamic response of trees to wind (O'Sullivan and Ritchie 1993; James et al. 2006). These factors were not considered in this research, but may significantly affect decisions made by tree risk assessors. More research is therefore needed to determine critical 


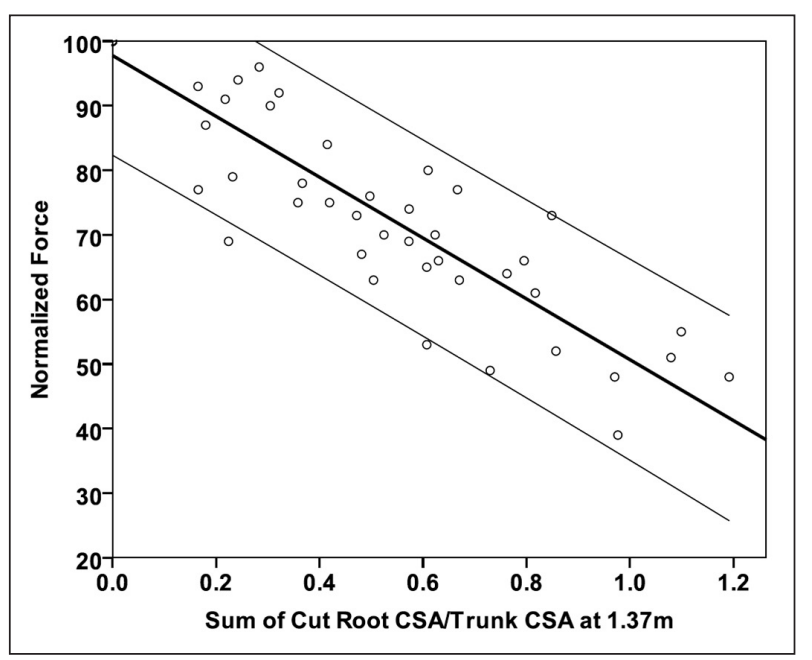

Figure 7. Regression line and $95 \%$ confidence interval for the comparison of the cumulative sum of the measured cross-sectional area of all roots that were severed divided by cross-sectional area of the trunk as measured at $1.37 \mathrm{~m}$ $\left(\sum R_{\text {cut area }} / C_{\text {trunk }} \times 100\right)$ compared to the normalized force $\left(F_{\text {Std }}=\right.$ peak force to move the trunk one degree after root cutting divided by the peak force prior to cutting roots multiplied by 100) to move the trunk one degree. This assessment procedure was defined at Method 4. $\mathrm{F}_{\mathrm{Std}}=97.7-47.1$ $\left(\sum R_{\text {cut area }} / \mathrm{CSA}_{\text {trunk }} \times 100\right), \mathrm{r}^{2}=0.82$.

root loss number for additional tree species, larger trees, and for trees where roots were lost years prior to inspection in dynamic wind situations.

Acknowledgments. We would like to recognize Robert A. Bartlett, Jr. and the F.A. Bartlett Tree Expert Company for their continuing support of arboricultural research.

This research project was conducted at the 2010 Biomechanics Week in

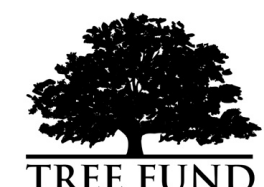

Cultivating Innovation
Shalerville, Ohio. We would like to express our appreciation to the efforts of John Goodfellow and Ward Peterson in association with the TREE Fund, the Ohio Chapter of the ISA, and the Davey Tree Expert Company for organizing and hosting that event.

Our research team in Ohio included: Fred Fisher, Mark Hoenigman, Mark Noark, TJ Dutton, Ryan Lewis, Dr. Andrew Koeser, Alan Siewert, and Luana Vargas.

During and after the event we received assistance from Christine Bechtel, Dr. Jason Grabosky, Dr. Greg Dahle, and Dr. Jason Miesbauer. We greatly appreciate all of the hard work that they contributed to this project.

\section{LITERATURE CITED}

Brudi, E., and P. van Wassenaer. 2002. Trees and statics: Nondestructive failure analysis. In: E.T. Smiley and K.D. Coder (Eds.). Tree Structure and Mechanics Conference Proceedings. International Society of Arboriculture. Champaign, Illinois, U.S. 184 pp.

Busgen, M., E. Munch, and T. Thomas. 1929. The structure and life of forest trees. Chapman and Hall, London, England.

Coutts, M.P. 1983. Root architecture and tree stability. Plant and Soil 71:171-188.
Crook, M.J., and A.R. Ennos. 1996. The anchorage mechanics of deep rooted larch, Larix europea $\times$ L. japonica. Journal of Experimental Botany 47:1509-1517.

Dupuy, L., T. Fourcaud, and A. Stokes. 2005a. A numerical investigation into factors affecting the anchorage of roots in tension. European Journal of Soil Science 56:319-327.

Dupuy, L., T. Fourcaud, and A. Stokes. 2005b. A numerical investigation into the influence of soil type and root architecture on tree anchorage. Plant and Soil 278:119-134.

Fraedrich, B.R., and E.T. Smiley. 2002. Assessing the failure potential of tree roots. In: E.T. Smiley and K.D. Coder (Eds.). Tree Structure and Mechanics Conference Proceedings. International Society of Arboriculture. Champaign, Illinois, U.S. 184 pp.

Ghani, M.A., A. Stokes, and T. Fourcaud. 2009. The effect of root architecture and root loss through trenching on the anchorage of tropical urban trees (Eugenia grandis Wight). Trees 23:197-209.

Hamilton, W.D. 1998. Significance of root severance on performance of established trees. Journal of Arboriculture 14(12):288-292.

ITFD. 2013. International Tree Failure Database. Accessed 04/25/2013. <http://ftcweb.fs.fed.us/natfdb/reports.aspx>

James, K.R., N. Haritos, and P.K. Ades. 2006. Mechanical stability of trees under dynamic loads. American Journal of Botany 93:1361-1369.

Köstler J.N., E. Brückner, and H. Bibelriether. 1968. Die Wurzeln der Waldbäume. Hamburg und Berlin, Verlag Paul Parey: 284.

Lilly, S. 2011. Glossary of arboricultural terms. International Society of Arboriculture, Champaign, Illinois, U.S. 152 pp.

Matheny, N.P., and J.R. Clark. 1994. A photographic guide to the evaluation of hazard trees in urban areas. International Society of Arboriculture, Champaign, Illinois, U.S. 85 pp.

Mattheck, C., and H. Breloer. 1994. The body language of trees. The Stationary Office. Norwich, UK. 239 pp.

Mattheck, C., M. Teschner, and J. Schafer. 1997. Mechanical control of root growth: A computer simulation. Journal of Theoretical Biology 184:261-269.

Mickovski, S.B., and A.R. Ennos. 2002. A morphological and mechanical study of the root system of suppressed crown Scots pine. Trees-Structure and Function. 16:274-280.

Mickovski, S.B., and A.R. Ennos. 2003 Anchorage and asymmetry in the root system of Pinus peuce. Silva Fennica 37(2):161-173.

O'Sullivan, M.F., and R.M. Ritchie. 1993. Tree Stability in relation to cyclic loading. Forestry 66:69-82.

Smiley, E.T. 2008. Root pruning and stability of young willow oak. Arboriculture \& Urban Forestry 34:123-128.

Smiley, E.T., A. Key, and C. Greco. 2000. Root barriers and windthrow potential. Journal of Arboriculture 26(4):213-217.

Smiley, E.T., B.R. Fraedrich, and N. Hendrickson. 2002. Tree Risk Management. Bartlett Tree Expert Co. 44 pp.

Smiley, E.T., N. Matheny, S. Lilly. 2011. Best Management Practices: Tree Risk Assessment. International Society of Arboriculture. Champaign, Illinois, U.S. 81pp.

Soil Survey of Portage County, Ohio. 1978. U.S. Dept. of Agric. Soil Conservation Service. 113 pp.

Stokes A., and C. Mattheck. 1996. Variation of wood strength in tree roots. Journal of Experimental Botany. 47:693-699.

Stokes, A. 1999. Strain distribution during anchorage failure of Pinus pinaster at different ages and tree growth response to wind-induced root movement. Plant and Soil 217:17-27. 
E. Thomas Smiley, Ph.D. (corresponding author) Arboriculture Researcher

R.A. Bartlett Tree Research Laboratories Charlotte, North Carolina, U.S.

Adjunct Professor

Clemson University

Clemson, South Carolina, U.S.

Liza Holmes

Research Technician

R.A. Bartlett Tree Research Laboratories

Charlotte, North Carolina, U.S.

Bruce R. Fraedrich, Ph.D.

Director

R.A. Bartlett Tree Research Laboratories

Charlotte, North Carolina, U.S.
Zusammenfassung. Die Absicht dieser Studie liegt in der Bewertung des Einflusses vom Rückschnitt von brettartigen Haltewurzeln auf die Baumstabilität und im Vergleich verschiedener Methoden, variierende Wurzelparameter mit Stärkegraden zu korrelieren. Zehn Rotahorne (Acer rubrum) aus der Baumschule wurden bis zu einem Grad aus der Vertikalen mit gemessenen Kräften gezogen, anschließend wurden die Wurzeln individuell nahe des Stammfusses abgetrennt und die Zugversuche wiederholt bis ca. 50 $\%$ der Wurzeln (der halbe Umfang) gekappt waren. Die Testbäume hatten 6 - 10 Haltewurzeln. Es gab eine fast direkte lineare Korrelation zwischen der Anzahl der entfernten Wurzeln und der eingesetzten Zugkraft. Im Vergleich von vier Untersuchungsmethoden zur Bestimmung von Zugkräften in Verbindung mit Wurzelkappen, war die Methode, die die größte Variabilität erklärbar durch die Regression aufwies, der Vergleich des Querschnittes der Wurzelschnitte zur eingesetzten Kraft. Dennoch konnte die Relation des Anteils der gekappten Haltewurzeln zur Zugkraft nur eine etwas weniger akkurate Information liefern und war einfacher vor der Baumfällung zu erheben.

Resumen. El propósito de este estudio fue evaluar los efectos de la poda de raíces de sostén en la estabilidad del árbol y comparar diferentes métodos de correlación de los distintos parámetros de la raíz a los niveles de fuerza. Diez Acer rubrum (arce rojo) de plantación fueron sacados a un ángulo de un grado de la vertical con fuerza medida. A continuación, las raíces se cortaron de forma individual cerca del tronco y las pruebas de tracción se repitieron hasta que las raíces se habían podado del $50 \%$ de la circunferencia. Los árboles de prueba tenían entre 6 y 10 raíces de soporte. Hubo una relación lineal casi directa entre el número de raíces removidas y la fuerza aplicada. Al comparar cuatro métodos de evaluación para determinar el cambio de fuerza de tracción asociado con la poda de raíces, el método que tenía la mayor cantidad de variabilidad explicada por la regresión fue la comparación del área de sección transversal de las raíces cortadas. Sin embargo, la relación del porcentaje de raíces de soporte de corte/fuerza aplicada proporciona solo ligeramente información menos precisa y fue más fácilmente colectada antes de la remoción de los árboles. 